\title{
ABORIGINAL YOUTH OVERREPRESENTATION IN CANADIAN CORRECTIONAL SERVICES: JUDICIAL AND NON-JUDICIAL ACTORS AND INFLUENCE
}

\author{
NATE JACKSON*
}

The crisis of Aboriginal over-incarceration in Canada is one of the most well-documented features of our Criminal Justice System. This crisis is especially profound in the youth context. While the Youth Criminal Justice Act (YCJA) has reduced Canada's overall youth incarceration rate in recent years, the relative proportion of detained Aboriginal youth has actually increased. This article explores Aboriginal youth overrepresentation in correctional services under the YCJA in an attempt to discern why it has been less effective at reducing custody rates for Aboriginal youth compared to their non-Aboriginal peers.

This article suggests that the YCJA has failed to remedy Aboriginal youth overrepresentation because it has focused too heavily on sentencing principles and judicial discretion. It is argued that more attention must be paid to the earlier stages of the criminal justice process during which Police, Crown Attorneys, and Probation Officers exercise low-visibility discretion in ways that disproportionately circumscribe the eventual range of sentencing options available to Aboriginal youth offenders.
La surincarcération des Autochtones au Canada constitue l'un des dossiers les mieux documentés du système de justice pénale. Cette situation est particulièrement grave pour les jeunes. Bien que la Loi sur le système de justice pénale pour les adolescents ait réduit le taux général d'incarcération des jeunes au cours des dernières années, la proportion relative des jeunes Autochtones, elle, a en fait augmenté. L'article examine la surreprésentation des jeunes Autochtones dans les Services correctionnels en vertu de la Loi dans l'espoir d'établir pourquoi elle s'est avérée moins efficace à réduire les taux d'emprisonnement des jeunes autochtones par rapport aux jeunes du reste de la population.

Cet article porte à croire que la Loi n'a pas remédié à la question de la surreprésentation des jeunes autochtones parce qu'elle accorde trop d'importance aux principes de détermination de la peine et de la discrétion judiciaire. L'auteur fait valoir qu'il faut accorder plus d'attention aux premières étapes du processus de justice pénale, c'est-à-dire lorsque la police, les procureurs de la Couronne et les agents de probation font preuve d'une discrétion réduite contournant de manière disproportionnée la portée finale les options de détermination de la peine applicabless aux jeunes délinquants autochtones.

\section{TABLE OF CONTENTS}

I. INTRODUCTION . . . . . . . . . . . . . . . . . . . . . . . . . . . . . . . 928

II. A ViCIOUS CYCLE:

COLONIALISM's INTERGENERATIONAL IMPACT . . . . . . . . . . . . . . . 929

III. THE CJS'S RESPONSE TO ABORIGINAL

OVER-INCARCERATION: A FOCUS ON SENTENCING . . . . . . . . . 932

IV. THE YOUTH CONTEXT: THE APPLICABILITY OF

SECTION 718.2(E) AND THE GLADUE PRINCIPLES . . . . . . . . . . . . . . . 934

V. ABORIGINAL YOUTH IN CORRECTIONAL SERVICES:

OVERREPRESENTATION UNDER THE YCJA . . . . . . . . . . . . . . . . 934

A. REMAND CUSTODY . . . . . . . . . . . . . . . . . . . . . . . 935

B. Sentenced Custody $\ldots \ldots \ldots \ldots \ldots \ldots \ldots \ldots \ldots \ldots \ldots \ldots \ldots$

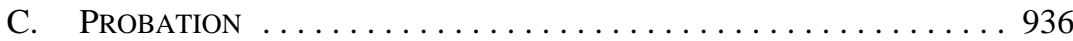

Nate Jackson, BAH (Queens) MA (UWO) JD (Osgoode). Many thanks to Ronda Bessner and Anthony Doob for their insightful feedback. Naturally, any errors or omissions remain the author's own. This article is dedicated to Indigenous lawyers, law students, Gladue writers, and caseworkers. Your courage and brilliance inspires and guides. 
D. Possible Implications $\ldots \ldots \ldots \ldots \ldots \ldots \ldots \ldots \ldots \ldots \ldots$

VI. THE IMPACT OF NON-JUdiCIAL ACTORS UNDER THE YCJA . . . . . . . . 937

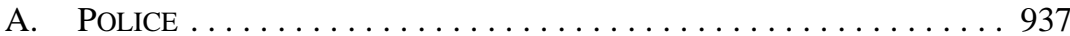

B. Crown Prosecutors . . . . . . . . . . . . . . . . . . . . . . . . 940

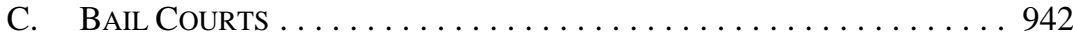

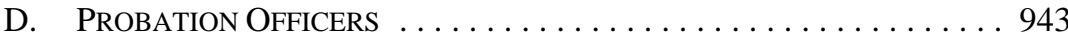

E. INHIBITING THE GLADUE CONSIDERATIONS:

NON-JUdiCIAL DisCRETION IMPACTS SENTENCING . . . . . . . . . . 944

VII. EXPANDING THE FOCUS: THE GLADUE PRINCIPLES

SHOUld Guide PRE-SENTENCE PROCEEDINGS AND THE

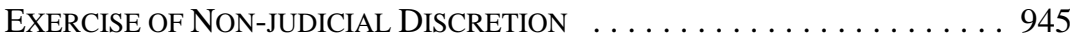

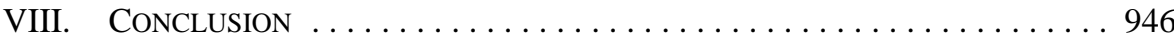

\section{INTRODUCTION}

The crisis of Aboriginal over-incarceration in Canada is one of the most well-documented features of our criminal justice system (CJS). ${ }^{1}$ This crisis is especially profound in the youth context and has been thrown into sharp relief under the Youth Criminal Justice Act. ${ }^{2}$ While Canada's overall youth incarceration rate has fallen by 35 percent under the YCJA, Aboriginal youth have only seen a 23 percent decrease in incarceration rates. ${ }^{3}$ In addition, Aboriginal youth are increasingly being held in remand custody and for longer periods of time than non-Aboriginal youth. ${ }^{4}$ Likewise, Aboriginal youth are disproportionately sentenced to probation. ${ }^{5}$ Contrasting starkly with the YCJA's laudable successes, these adverse trends highlight the depths and endurance of Canada's Aboriginal over-incarceration crisis. This article explores Aboriginal youth overrepresentation in correctional services under the YCJA in an attempt to discern why it has been less effective at reducing custody rates for Aboriginal youth compared to their non-Aboriginal peers.

First, this article discusses the historical legacy of colonialism and its intergenerational contribution to Aboriginal over-incarceration. Next, the CJS's response to this crisis embodied by section 718.2(e $)^{6}$ and the Gladue $e^{7}$ line of cases - is discussed. Importantly, the extent to which this response has been imported into the YCJA is noted. Having established this critical contextual framework, this article then details the current state of Aboriginal overrepresentation in youth correctional services by looking more closely at the use of remand custody, custodial sentences, and probation. Next, this article assesses the prospect that non-judicial actors function to effectively expand or confine the eventual range of sentencing options available, thus stymying any constructive impact the judicial consideration of a youth's Aboriginality might otherwise have. Ultimately, this article suggests that the CJS has attempted to remedy Aboriginal youth overrepresentation by

Brian R Pfefferle, "Gladue Sentencing: Uneasy Answers to the Hard Problem of Aboriginal OverIncarceration” (2008) 32:2 Man LJ 113 at 143.

SC 2002, с 1 [YCJA].

Statistics Canada, "Youth custody and community services in Canada, 2008/2009," by Donna Calverley, Adam Cotter \& Ed Halla, in 30:1 Juristat, Catalogue No 85-002-X (Ottawa: Statistics Canada, 2010) at 31, online: <www.statcan.gc.ca/pub/85-002-x/2010001/article/11147-eng.pdf >.

Ibid at 30, 32.

Ibid at 13, 29.

Criminal Code, RSC 1985, c C-46 [Code].

$R \vee$ Gladue, [1999] 1 SCR 688 [Gladue]. 
focusing too discretely on sentencing principles and judicial discretion. It is argued that more attention must be paid to the earlier stages of the criminal justice process. In particular, the discretionary power wielded by the police and the Crown must be emphasized as a key variable in the over-incarceration equation.

\section{A Vicious CyCLE: COLONIALISM'S INTERGENERATIONAL IMPACT}

The multi-layered crisis of Aboriginal over-incarceration can only be fully understood when framed around the unique Aboriginal experience of Canadian colonialism. ${ }^{8}$ Contrary to what Prime Minister Stephen Harper has publicly stated, Canada has a deep history of colonialism. ${ }^{9}$ While mainstream conceptions of Canadian history continue to characterize "pre-contact” North America as a terra nullius - a land void of political and social structure that European settlors simply filled - the truth is quite the contrary. The fact that an internally diverse array of Indigenous nations existed in North America since time immemorial has, however, always been problematic from a settlor perspective. ${ }^{10}$ As Europeans immigrated to North America in greater numbers and Canada began the process of nation-building, Indigenous peoples were suddenly viewed as being "in the way" of the state's march toward modernity. In lieu of outright conquest, ${ }^{11}$ successive Canadian governments attempted to systematically eliminate the country's purported "Indian Problem"12 via deliberate and calculated state policies.

The criminalization of Indigenous culture and traditions, the continued occupation of unceded land and the ongoing practice of ignoring treaty obligations are but a few examples of how the Canadian state has endeavored to “deal with” Aboriginal peoples. ${ }^{13}$ Markedly traumatic and violent, the attempted assimilation of Aboriginal youth via the Residential School System and the "Sixties Scoop" have been held as the most tangible examples of

The necessity of considering Aboriginal over-incarceration in relation to colonialism was most notably established by The Royal Commission on Aboriginal Peoples, Bridging the Cultural Divide: A Report on Aboriginal People and Criminal Justice in Canada (Ottawa: Supply and Services Canada, 1996) at 5-11 [RCAP].

$9 \quad$ At a G20 summit in 2009, Harper infamously touted Canada's enviable position on the global stage by stating, "We also have no history of colonialism. So we have all of the things that many people admire about the great powers but none of the things that threaten or bother them." See David Ljunggren, "Every G20 nation wants to be Canada, insists PM," Reuters (25 September 2009), online: <www. reuters.com/article/2009/09/26/columns-us-g20-canada-advantages-idUSTRE58P05Z20090926>.

Please note that this article's discussion of "Aboriginal peoples" in Canada is inherently problematic in that those Indigenous to this land are an internally heterogeneous affiliation. They are, however, bound by the commonality of their indigeneity and the adversarial position the Canadian state has taken against this indigeneity. It is in the context of this commonality that this article assesses the enduring impact of colonialism on Aboriginal people. See Laurence J Kirmayer, Caroline L Tait \& Cori Simpson, "The Mental Health of Aboriginal Peoples in Canada: Transformations of Identity and Community" in Laurence J Kirmayer \& Gail Guthrie Valaskakis, eds, Healing Traditions: The Mental Health of Aboriginal Peoples in Canada (Vancouver: UBC Press, 2009) 3 at 6.

11 Haida Nation v British Columbia (Minister of Forests), 2004 SCC 73, [2004] 3 SCR 511 at para 25.

12 The search for a final solution to Canada's "Indian Problem" was dubiously undertaken by Prime Minister Pierre Trudeau and then Indian Affairs Minister (and future PM) Jean Chrétien. Their efforts culminated in the infamous "White Paper.” See Rudolph C Rÿser, Indigenous Nations and Modern States: The Political Emergence of Nations Challenging State Power (New York: Routledge, 2012) at 74-75.

$13 \quad$ RCAP, supra note 8 at 5-11. 
modern colonialism in Canada. ${ }^{14}$ Whether these policies amount to benevolent ethnocide, ${ }^{15}$ or are characterized as inherently genocidal, ${ }^{16}$ they ultimately failed to "solve" the Indian Problem. They did, however, succeed in further marginalizing Aboriginal peoples. Coercively confined to the fringes of society, Aboriginal communities in Canada have been left with a resultant host of societal ailments that continue to feedback upon one another in a vicious cycle.

Aboriginal interaction with the Canadian legal system has featured prominently within this cycle. Critically, these interactions must continue to be viewed through a colonial lens. Although colonialism is arguably less obvious in what has become known as a "postcolonial" age ${ }^{17}$ its enduring legacy remains on daily display in courthouses across the country. Here, innumerable styles of cause lay bare the adversarial relationship that exists between Aboriginal peoples and the Canadian state. Delgamuukw v. British Columbia; ${ }^{18} R$. v. Amitook; ${ }^{19}$ Children's Aid Society of the County of Renfrew v. Algonquins of Pikwákanagán: ${ }^{20}$ these are the battle lines over which contemporary colonialism is simultaneously asserted and resisted. The halls of criminal justice, in particular, have become a central locus of adversarial activity in which Aboriginal individuals are literally pitted against the Crown. In a legal arena built and managed by the state, however, it is perhaps unsurprising that Indigenous peoples have most often found themselves on the losing end of such a match-up.

As alluded to above and explained more fully in the youth context below, Aboriginal interaction with the CJS has resulted in endemic rates of over-incarceration. Over the last 30 years, countless investigations have produced a wealth of unambiguous data on the subject. ${ }^{21}$ Although recent statistics include minor variations depending on jurisdiction and method of analysis, a conservative estimate places the proportion of Aboriginal adults in custody in Canada at seven to eight times higher than the proportion of Aboriginal adults in the Canadian population as a whole. ${ }^{22}$ In short, Aboriginal overrepresentation in Canadian jails and remand facilities is an established fact.

The "Sixties Scoop" refers to a 1965 agreement between the Federal Crown and "Child Welfare Services" that allowed "a well-intentioned but profoundly uninformed child protection bureaucracy to 'scoop' thousands of Indian children that were found to be in need of protection off Indian reserves and place them in non-aboriginal homes.” See Brown v Canada (Attorney General), 2013 ONSC 5637, [2014] 1 CNLR 1 at paras 6, 11-22.

15 Murray Sinclair, “A Presentation to the Western Workshop of the Western Judicial Education Centre” in Jennie Abell, Elizabeth Sheehy \& Natasha Bakht, Criminal Law \& Procedure: Cases, Context, Critique, 5th ed (Concord, Ont: Captus Press, 2012) 86 at 87.

16 Phil Fontaine \& Bernie Farber, "What Canada committed against First Nations was genocide. The UN should recognize it,” The Globe and Mail (14 October 2013), online: <www.theglobeandmail.com/ globe-debate/what-canada-committed-against-first-nations-was-genocide-the-un-should-recognizeit/article14853747>.

17 Peter Childs \& RJ Patrick Williams, An Introduction to Post-Colonial Theory (Essex, UK: Prentice Hall, 1997) at 1.

[1997] 3 SCR 1010.

2006 QCCQ 2705, [2006] 3 CNLR 249.

2012 ONSC 4518, [2012] OJ No 3756 (QL).

Jonathan Rudin \& Kent Roach, “Broken Promises: A Response to Stenning and Roberts' 'Empty Promises”” (2002) 65:1 Sask L Rev 3 at 6-11.

22 Statistics Canada, “Adult correctional statistics in Canada, 2010/2011,” by Mia Dauvergne, in Juristat, Catalogue No 85-002-X (Ottawa: Statistics Canada, 2012) at 11, online: <www.statcan.gc.ca/pub/85002-x/2012001/article/11715-eng.pdf>. 
In 1996, the Royal Commission on Aboriginal Peoples emphasized the causal role colonialism plays in Aboriginal over-incarceration. Even so, many commentators continue to point toward socio-economic deprivation and contemporary Aboriginal poverty as the sole drivers of overrepresentation. ${ }^{23}$ Although socio-economic factors are closely correlated with criminal activity across all demographics, the unique process by which Indigenous peoples were systematically marginalized in Canada has produced a distinct outcome. As Justice Turpel-Lafond has described:

We have to accept that there are profound social and economic problems in Aboriginal communities today that never existed pre-colonization and even in the first few hundred years of interaction. Problems of alcohol and solvent abuse, family violence and sexual abuse, and youth crime - these are indications of a fundamental breakdown in the social order in Aboriginal communities of a magnitude never known before. ${ }^{24}$

This "fundamental breakdown" includes an intergenerational mental health component that further exacerbates Aboriginal interaction with the CJS. ${ }^{25}$

Passed down from parents and grandparents traumatized by the Residential School experience, heightened levels of anxiety and stress have been inherited by Aboriginal youth. ${ }^{26}$ Simply put: the physical and mental anguish stemming from colonialism does not just dissipate over time. Rather, in the absence of substantive reconciliation for past harms, ${ }^{27}$ this pain is pressurized as the years pass. Compounded by contemporary racism and an overarching loss of identity, the effect on Aboriginal youth is all the more toxic and has lead, in combination with other factors, ${ }^{28}$ to increased interaction with the CJS. ${ }^{29}$

While this article can only scratch the surface in its discussion of the ongoing trauma caused by the Residential School System and other assimilationist state policies, it attempts to further the foundational acknowledgement that the legacy of colonialism is centrally

23 Rudin \& Roach, supra note 21 at 17-19.

24 Mary Ellen Turpel, "Reflections on Thinking Concretely about Criminal Justice Reform” in Richard Gosse, James Youngblood Henderson \& Roger Carter, eds, Continuing Poundmaker and Riel's Quest: Presentations Made at a Conference on Aboriginal Peoples and Justice (Saskatoon: Purich Publishing, 1994) 206 at 209, cited in Jonathan Rudin, Aboriginal Peoples and the Criminal Justice System (Toronto: Ipperwash Inquiry, 2013) at 27, online: <www.archives.gov.on.ca/en/e_records/ipperwash/ policy_part/research/pdf/Rudin.pdf $>$ [Rudin, Criminal Justice System]. Mary Ellen Turpel-Lafond, a member of the Cree First Nation, was name to the Saskatchewan provincial bench in 1998 at the age of 35: Justine Hunter, “Making a case for children at risk; Current system doesn't understand needs of its change, watchdog says after 4 months” The Globe and Mail (7 August 2007) (Factiva).

25 Sarah Nelson, Challenging Hidden Assumptions: Colonial Norms as Determinants of Aboriginal Mental Health (Prince George: National Collaborating Centre for Aboriginal Health, 2012), online: $<$ www.nccah-ccnsa.ca/Publications/Lists/Publications/Attachments/70/colonial_norms_EN_web.pdf > .

26 Karina Czyzewski, “Colonialism as a Broader Social Determinant of Health” (2011) 2:1 Intl Indigenous Policy J 5 at 7.

27 While some might point to Canada's recent Truth and Reconciliation Commission (TRC) and the reparations made therein as an example of the Canadian government attempting to make amends, others have viewed the TRC as a problematic stop-gap: a 21st Century strategy to "deal with” Canada's colonial past. See Linda Diebel, "No truth, no reconciliation for aging residential school survivors," The Toronto Star (23 July 2010), online: <www.thestar.com/news/canada/2010/07/23/no_truth_no_ reconciliation_for_aging_residential_school_survivors.html $>$.

28 While many Aboriginal people have been driven to increased criminal activity, an important part of the over-incarceration equation also involves over-policing and discriminatory law enforcement strategies as discussed below.

29 Simha F Landau, "Crime Patterns and Their Relation to Subjective Social Stress and Support Indicators: The Role of Gender” (1997) 13:1 J Quantitative Criminology 29. See also Annie K Yessine \& James Bonta, “The Offending Trajectories of Youthful Aboriginal Offenders” (2009) 51:4 Can J Corr 435 at 458-59. 
implicated in Aboriginal over-incarceration in Canada. The CJS has recently adopted this perspective in its relatively recent attempt to address this verifiable crisis.

\section{THE CJS'S RESPONSE TO ABORIGINAL OVER-INCARCERATION: A FOCUS ON SENTENCING}

The CJS's response to the crisis of Aboriginal over-incarceration has primarily focused on sentencing. In 1995, around the same time Royal Commission on Aboriginal Peoples released its influential report, Parliament enacted sentencing provisions that called on the courts to pay particular attention to the unique circumstances of Aboriginal offenders. This portion of Bill C-41 ${ }^{30}$ was codified in section 718.2(e) of the Code, which states:

718.2 A court that imposes a sentence shall also take into consideration the following principles:

(e) all available sanctions other than imprisonment that are reasonable in the circumstances should be considered for all offenders, with particular attention to the circumstances of aboriginal offenders. $^{31}$

As then Justice Minister Alan Rock made clear at the time of Bill C-41's passing, this provision was aimed explicitly at mitigating the crisis of Aboriginal over-incarceration. ${ }^{32}$ In spite of its publicly stated purpose, the provision provoked uncertainty regarding its proper application to sentencing procedure. Thus, the Supreme Court of Canada seized on the case of Gladue in an attempt to clarify section 718.2(e).

In Gladue, the Supreme Court held that section 718.2(e) instructs judges to consider colonialism's enduring impact on Aboriginal offenders with an eye toward stemming their overrepresentation in custodial facilities. In addition to taking "judicial notice of the broad systemic and background factors affecting aboriginal people,"33 the Supreme Court guided sentencing courts to look at two sets of factors when sentencing an Aboriginal offender. These factors are:

(A) The unique systemic or background factors which may have played a part in bringing the particular aboriginal offender before the courts; and

(B) The types of sentencing procedures and sanctions which may be appropriate in the circumstances for the offender because of his or her particular aboriginal heritage or connection. ${ }^{34}$

An Act to Amend the Criminal Code (sentencing) and other Acts in consequence thereof, SC 1995, c 22, s 6 .

Supra note 6.

House of Commons, Standing Committee on Justice and Legal Affairs, Mintues of Proceedings and Evidence of the Standing Committee on Justice and Legal Affairs, 35th Parl, 1st Sess, No 62 (17 November 1994) at 15, cited in Jonathan Rudin, “Aboriginal Over-representation and R. v. Gladue: Where We Were, Where We Are and Where We Might Be Going” (2008) 40 SCLR (2d) 687 at 690 [Rudin, “Aboriginal Over-representation”]. 
Noting that a fruitful consideration of these issues requires access to contextual information pertaining to the individual offender and their particular background, the Supreme Court went on to discuss the important role counsel submissions and pre-sentence reports (PSRs) will play. ${ }^{35}$ In light of the information revealed by these reports, the Supreme Court held that "the jail term for an aboriginal offender may in some circumstances be less than the term imposed on a non-aboriginal offender for the same offence."36 Although decried by critics as providing Aboriginal offenders with a "get out of jail free card," the Supreme Court's landmark decision in Gladue has since been firmly entrenched within the Canadian common law and institutionalized within the CJS itself. ${ }^{37}$

The Supreme Court of Canada's recent decision in $R$. $v$. Ipeelee $e^{38}$ reaffirms the applicability of section 718.2(e) as per Gladue. It also reflects the CJS's narrow focus on sentencing as the primary front on which Aboriginal over-incarceration is being fought. While the Court in Ipeelee acknowledged the fact that Aboriginal overrepresentation in correctional services has actually increased since section 718.2(e) was enacted, it holds that this "failure can be attributed to some extent to a fundamental misunderstanding and misapplication of both" the provision itself and the Supreme Court's guidance. ${ }^{39}$ On one hand, the Supreme Court in Ipeelee conceded that sentencing judges can only play a "limited role ... in remedying injustice against aboriginal peoples in Canada." ${ }^{40}$ On the other hand, the Supreme Court seems to reaffirm their admittedly optimistic view that sentencing judges can make a positive difference. ${ }^{41}$ In almost the same breath, the Supreme Court is acknowledging the restricted ability of sentencing judges to turn back the tide of Aboriginal over-incarceration while also expressing the importance of what little positive impact can be made. This article suggests that this sentiment reflects the CJS's response to the crisis more generally: it is committed to addressing Aboriginal over-incarceration by maintaining its admittedly narrow — focus on sentencing. ${ }^{42}$ While the potential pitfalls of this approach are canvassed in more detail below, the extent to which this myopic focus has been imported into the youth criminal justice context is important to consider.

\footnotetext{
35 Ideally these reports should be compiled by specially trained Aboriginal case workers. While the use of "Gladue Reports" (as they are fittingly referred to) is prevalent in larger jurisdictions, access is limited throughout the country. Although PSRs written by probation officers have been held as an acceptable substitute in certain circumstances, the value of such a report is somewhat compromised. See $R v$ Kakekagamick (2006), 81 OR (3d) 664 (CA) at para 45.

Supra note 7 at para 93.

In addition to Gladue Reports, some jurisdictions have set up specialized Gladue Courts that field cases involving Aboriginal accused and offenders. See Aboriginal Legal Services of Toronto, "Gladue Court," online: <www.aboriginallegal.ca/\#!gladue-court/ceu2>. 2012 SCC 13, [2012] 1 SCR 433 [Ipeelee].

Ibid at para 63.

Ibid at para 61, quoting Gladue, supra note 7 at para 65.

Ibid.

While recent case law indicates an expanded application of the Gladue principles beyond sentencing, their applicability is still confined to the realm of judicial discretion. As such, this article argues that Gladue has been held to apply too late in the proceedings and stands to be much more effectively applied earlier on. See e.g. Rudin, “Aboriginal Over-representation,” supra note 32 at 700.
} 


\section{THE YouTh CONTEXT: THE APPLICABILITY OF SECTION 718.2(E) AND THE GLADUE PRINCIPLES}

While the YCJA explicitly precludes the application of adult sentencing provisions in youth proceedings, it carves out an exception for section 718.2(e) of the Code. ${ }^{43}$ Interestingly, while earlier drafts of the YCJA did not include this exception, they did include provisions that called for general restrictions on custodial sentencing for all young offenders and the general consideration of "ethnic, cultural and linguistic differences." 44 Arguing that these general provisions were much too vague and permissive, community groups including Aboriginal Legal Services of Toronto were ultimately successful in convincing Parliament that a young offender's Aboriginality must be considered. ${ }^{45}$ As such, section $718.2(\mathrm{e})$ of the Code - and the dicta flowing from it through the Gladue line of cases — still applies to youth proceedings via section 50 of the YCJA. The additional inclusion of section 38(2)(d) of the YCJA, which essentially replicates the relevant Code provision cited above, reinforces the necessary consideration of a youth offender's indigeneity. Moreover, the Courts are directed to more broadly consider the unique "needs of aboriginal young persons" as per the YCJA's Declaration of Principle. ${ }^{46}$ The eventual inclusion of these provisions and the particular emphasis placed on the sentencing of Aboriginal youth offenders is - as in the adult context - a byproduct of the CJS's chosen approach to the crisis of over-incarceration.

As this article has made clear, the CJS's reaction to the crisis of Aboriginal overincarceration in both the adult and youth context has most notably focused on sentencing. As cases like Gladue reveal, this strategy is commendably anchored in an appropriate understanding of colonialism and its enduring impact on many Aboriginal communities and individual offenders. As the Supreme Court of Canada has itself hinted, however, this approach - when confined to the sentencing stage of proceedings — is inherently limited. In order to assess just how limited this approach has proven to be in the youth context, this article now proceeds to explore the recent trends in Aboriginal youth incarceration under the YCJA.

\section{Aboriginal Youth in CoRrectional SERVICEs: OVERREPRESENTATION UNDER THE YCJA}

It is often said that the devil is in the details. Unfortunately, this saying holds true when analyzing Aboriginal youth custody data. Proponents of the YCJA have understandably cited the decline in Canada's overall youth custody rate as proof of the legislation's success. ${ }^{47}$ Furthermore, some investigators have been quick to point out that the rate of Aboriginal youth admitted to sentenced custody has also decreased in absolute terms. ${ }^{48}$ With less Aboriginal youth behind bars, they argue, is the problem not being addressed? Critically, however, while the "custodial pie” has laudably shrunk, the Aboriginal piece of this pie has

$43 \quad$ YCJA, supra note 2, s 50.

$44 \quad$ Marian Jacko \& Jonathan Rudin, Brief to the Standing Committee on Justice and Human Rights on Bill C-3 (Youth Criminal Justice Act) From Aboriginal Legal Services of Toronto (1 March 2000) at 4, online: <www.aboriginallegal.ca/\#!youth-criminal-justice-act/c1xnd>.

Ibid at 3.

Supra note 2, s 3(1)(c)(iv).

Nicholas Bala, Peter J Carrington \& Julian V Roberts, “Evaluating the Youth Criminal Justice Act after Five Years: A Qualified Success” (2009) 51:2 Can J Corr 131.

Calverley, Cotter \& Halla, supra note 3 at 31. 
actually grown. In other words, the proportion of Aboriginal youth admitted to correctional services has grown under the YCJA. ${ }^{49}$ This article breaks down this adverse increase with reference to three categories of correctional admissions: remand custody, sentenced custody, and probation.

\section{A. REMAND Custody}

Data compiled by Statistics Canada during the first five years of the YCJA's coming into force reveal an increase in the proportion of Aboriginal youths admitted to remand custody. Between 2004 and 2009, the proportion of male Aboriginal youth admitted to remand custody increased from 21.7 percent to 25.0 percent of total male youth remand admissions. ${ }^{50}$ Similarly, the proportion of female Aboriginal youth admitted to remand custody increased from 27.1 percent to 33.6 percent during this same time frame. ${ }^{51}$ Given that Aboriginal youth continued to make up 6 percent of the overall Canadian youth population (for both genders) during this period, this growing disproportionality in remand admissions is significant.

In addition to being over-represented in remand custody admissions, data shows that Aboriginal youth who are denied bail tend to spend more days in remand than their nonAboriginal peers. Based on statistics gathered in Ontario, Alberta, Newfoundland and Labrador, and British Columbia, Aboriginal youth admitted into remand custody in 2008/2009 served a median of nine days. ${ }^{52}$ Non-Aboriginal youth admitted into remand custody served a median of six days. These lengthier stays in remand facilities for Aboriginal youth were consistent across most offence types. ${ }^{53}$ Thus, Aboriginal overrepresentation in remand custody is doubly problematic.

\section{B. SENTENCED CUSTODY}

Similar trends appear to exist regarding the proportion of Aboriginal youth admitted to sentenced custody in the wake of the YCJA. Between 2004 and 2009, the disproportionate rate of Aboriginal male youths sentenced to custody rose from 29.2 percent to 34.1 percent. ${ }^{54}$ Unfortunately, increased disproportionality on the female side has been much more severe as female Aboriginal youth went from making up 36.6 percent of custodial admissions in 2004/2005 to 44.1 percent in 2008/2009. ${ }^{55}$ Therefore, as these figures indicate, Aboriginal youth over-incarceration appears to be worsening.

As mentioned above, it is worth noting that the absolute number of Aboriginal youth sentenced to custody does appear to be on the decline. Yet, while the number of male Aboriginal youth admitted into sentenced custody decreased by 26 percent between 2004 and

Ibid.

Ibid at 30 .

Ibid. Over and above the increase in the disproportionality of Aboriginal remand admissions, male and female Aboriginal admissions also increased in absolute numbers between 2004-2009 — hitting all-time highs in 2008. However, given that absolute non-Aboriginal remand admissions had also increased up until 2008 (dropping back below 2004 levels only in 2008/2009), these figures are arguably less indicative of divergent trends.

Ibid at 32 .

Ibid at 33 .

Ibid at 31.

Ibid. 
2009, the male non-Aboriginal youth custody rate dropped by 41 percent. ${ }^{56}$ Likewise, while the number of female Aboriginal youth sentenced to custody decreased by 12 percent, the non-Aboriginal female custody rate fell by 35 percent. Simply put: non-Aboriginal youth custody rates are being curbed much faster than Aboriginal youth custody rates. ${ }^{57}$

\section{Probation}

As one might expect, Aboriginal youth are also disproportionately subject to probation orders. In 2008/2009, Aboriginal male youths made up 22 percent of all male youths sentenced to probation. ${ }^{58}$ Predictably, an even higher proportion (31 percent) of female youths subject to probation orders were Aboriginal. While the dataset relied upon does not chart changes in the number of youths sentenced to probation, the disproportionate rates recorded in 2008/2009 are consistent with the broader trends noted above.

\section{POSSIBLE IMPLICATIONS}

According to the data set which this section relied upon, Aboriginal youths are overrepresented in remand custody, sentenced custody, and probation. This article suggests that these trends, when considered in context of the YCJA's Aboriginal-attuned sentencing provisions, reflect the inherent limitations of a sentencing-centric approach to Aboriginal over-incarceration. While this article does not discount the continued importance of the Gladue principles and the consideration of an Aboriginal youth's unique background at the sentencing stage, it does argue that these considerations - primarily confined as they are to the exercise of judicial discretion - simply are not constructively impacting Aboriginal youth over-incarceration.

Where do these limitations stem from? Are there particular aspects of the YCJA that function to stymie the CJS's attempt to curb the crisis? More specifically, do certain provisions of the YCJA that guide the earlier stages of the criminal justice process, in effect, "tie the hands" of sentencing judges? These are the questions this article now turns to answer in an attempt to better understand why the express consideration of Aboriginality mandated by the YCJA (codified in sections 38(2)(d) and 50) has not translated into lower overrepresentation. Ultimately, it is suggested that key provisions pertaining to pre-sentence stages have the disproportionate potential to adversely impact Aboriginal youth. From this perspective, special consideration of a youth's indigeneity before judicial discretion enters the equation is needed if Aboriginal youth overrepresentation is to be curbed under the YCJA. median custodial sentence length, it does indicate a significant discrepancy in Newfoundland and Labrador (80 vs 61 days) and Ontario (50 vs 40 days): ibid at 32. 


\section{THE IMPACT OF NON-JUDICIAL ACTORS UNDER THE YCJA}

Although sentencing judges are the final gatekeepers to correctional services, there are a number of key actors whose pre-sentence discretion functions to either confine or expand the range of options eventually available to judges during the sentencing stage. Moving temporally from a youth's initial interaction with the CJS to the final sentencing stage, this article now examines the potential for: (1) the police; (2) Crown prosecutors; (3) bail courts, and (4) probation officers to restrict the imposition of custodial alternatives for Aboriginal youth under the YCJA.

\section{A. Police}

Across all jurisdictions in Canada, the police play an instrumental role in deciding if and when the courts will formally become involved in a particular criminal incident. The use of this discretion has been encouraged by the YCJA and most likely contributed greatly to the overall decrease in criminal cases under it. ${ }^{59}$ However, given the variable racism that exists in police detachments across Canada, this discretion has potentially become a double-edged sword for Aboriginal youth. While some Aboriginal youth undoubtedly benefit from the measures discussed below, research shows that police are potentially more likely to respond informally to non-Aboriginal youth. The potential for differential action taken by police in response to criminal incidents is, therefore, discussed below in relation to the "downstream" implications for Aboriginal youth in the criminal justice process.

For youth apprehended for a relatively minor occurrence, the police have the discretion to simply not engage the machinery of the CJS such that the incident is treated more informally, like with a warning. ${ }^{60}$ This type of informal, out-of-court police response is encouraged by the $Y C J A^{61}$ and is generally captured by the term "extrajudicial measure" (EJM). ${ }^{62}$ As opposed to an extrajudicial sanction (EJS) outlined in sections 10-12 of the $Y C J A$, an EJM essentially allows a police officer to exercise his or her discretion not to charge a youth offender based on that officer's independent consideration of the circumstances. The principles underlying the use of EJMs are listed in the YCJA:

(a) extrajudicial measures are often the most appropriate and effective way to address youth crime;

(b) extrajudicial measures allow for effective and timely interventions focused on correcting offending behaviour; in 2002/2003 to 57,675 in 2004/2005. See Statistics Canada, "Youth court statistics in Canada, 2010/2011,” by Shannon Brennan, in Juristat, Catalogue No 85-002-X (Ottawa: Statistics Canada, 2012) at 20, online: <www.statcan.gc.ca/pub/85-002-x/2012001/article/11645-eng.pdf>. 40:4 Alta L Rev 991 at 1006.

$61 \quad$ YCJA, supra note 2, ss 4-9.

62 As Bala, supra note 60 points out at 1001-1002, the term "EJM" actually serves as an umbrella that encompasses informal police responses as well as more formal Crown-initiated extrajudicial sanctions. For clarity, however, this article refers to EJMs and extrajudicial sanctions as distinct processes initiated by the police and Crown, respectively. 
(c) extrajudicial measures are presumed to be adequate to hold a young person accountable for his or her offending behaviour if the young person has committed a non-violent offence and has not previously been found guilty of an offence; and

(d) extrajudicial measures should be used if they are adequate to hold a young person accountable for his or her offending behaviour and, if the use of extrajudicial measures is consistent with the principles set out in this section, nothing in this Act precludes their use in respect of a young person who

(i) has previously been dealt with by the use of extrajudicial measures, or

(ii) has previously been found guilty of an offence. ${ }^{63}$

Notably, individual officers are tasked with the unenviable job of balancing the above principles with the practical realities of policing.

Guided by the above principles, the YCJA relies on individual officers to consider the numerous contextual factors pertaining to a particular youth. In place of pursuing a formal legal charge, the police have a range of informal measures to choose from. As Bala outlines:

\begin{abstract}
When considering how to respond to a youth suspected of an offence, an officer may have a number of different options, depending on local resources and policies. The least intrusive response is for the officer who first comes in contact with the youth to personally warn the youth not to commit any further offences... The officer may contact the parents ... [and] discuss ... whether the offending behaviour is related to other problems that might be assisted by a social agency or doctor, or whether the child's school or church might be able to provide help. ${ }^{64}$
\end{abstract}

The decision to utilize an EJM as opposed to something more formal (and to decide what form the measure takes) is directly connected, therefore, to other aspects of the youth's personal circumstances such as family life, education, and so on. Additionally, while sections 4(d)(i) and (d)(ii) quoted above expressly discourage police from considering the fact that a youth has received an EJM in the past, recent research shows that this type of consideration looms large in many officers' decisions to utilize EJMs. ${ }^{65}$ While the consideration of factors extraneous to the incident itself makes sense in the context of addressing the underlying behaviour, it also opens the door for the inconsistent and unequal treatment of youth - and Aboriginal youth in particular - given the prevalence of discriminatory attitudes in certain communities across Canada.

The verifiable existence of systemic discrimination and enduring racist attitudes among police officers toward Aboriginal people provide reasonable grounds to believe that Aboriginal youths are more likely to be denied EJMs in favour of more formal responses. ${ }^{66}$

$63 \quad$ Supra note 2, s 4.

$64 \quad$ Supra note 60 at 1008.

65 Voula Marinos \& Nathan Innocente, "Factors Influencing Police Attitudes towards Extrajudicial Measures under the Youth Criminal Justice Act” (2008) 50:4 Can J Corr 469 at 481.

66 Indeed, police forces and other elements of the CJS have been seen to exhibit a concentrated level of racist attitudes toward Aboriginal people owing, in part, to their disproportionate level of contact. As one begins to see, these views and the cause of such views become mutually reinforcing. Rudin, Criminal Justice System, supra note 24 at 6, 36. 
Although potentially surprising to many progressive non-Aboriginal Canadians, ${ }^{67}$ communities across Canada continue to exhibit widespread feelings of racism and discrimination toward Aboriginal people in general. ${ }^{68}$ Unfortunately, the police often share these attitudes. ${ }^{69}$ As such, there may be a tendency for police to provide "a break" for nonAboriginal youths from "good families" while "prejudicing youths from disadvantaged backgrounds." ${ }^{\prime 70}$ This, in addition to the fact that Aboriginals are more likely to have come in contact with the police in the past, increases the likelihood that Indigenous youths will be denied EJMs. Given that police still consider a youth's past EJMs when deciding the appropriateness of future EJMs (contrary to the YCJA's guidance), the seriousness of the instant offence might not even factor into an officer's decision if a youth has come in contact with the CJS on a prior occasion. As one officer stated in an interview with researchers: "[d]eciding whether or not to use a warning when a young person has previously been charged with a criminal offence isn't hard for me. I do not do it. The nature of the offence doesn't matter to me."71

In the context of "over-policed"72 Aboriginal communities in which Aboriginal youth tend to have higher recidivism rates, this "no second chances" approach to EJMs likely contributes to a disproportionate amount of police incidents involving Indigenous youth being escalated to more formal proceedings. The fact that police engage in this approach contrary to Parliament's clearly articulated intention speaks to the dangers associated with purely discretionary EJMs.

Because the decision to proceed informally via an EJM involves what Bala has described as "low visibility" police discretion, there is no ability to track — let alone correct — the discriminatory use of said discretion. ${ }^{73}$ As it stands, the YCJA empowers police to decide to pursue formal charges or not with relative impunity. This article suggests that in the context of enduring racist attitudes and systemic discrimination within Canadian police services, this lack of accountability decreases the likelihood of EJMs being provided for Aboriginal youth. As a direct consequence, more Aboriginal youth are being ushered into formal court proceedings. Once within the confines of the CJS, this discretionary dynamic is reproduced via prosecutorial decision-making as Aboriginal youth go from the frying pan into the fire.

Given Canada’s self-perceived and self-purported identity as an idyllic “multicultural tossed salad” (as compared to the "melting pot" of the United States), progressive urban Canadians are sometimes surprised to learn that widespread racism exists in this country. Anupa Mistry, "Canada is Still Racist," Vice Magazine (5 March 2013), online: <www.vice.com/en_ca/read/canada-is-still-racist>.

Don McCaskill, "Discrimination and Public Perceptions of Aboriginal People in Canadian Cities" (2012) Urban Aboriginal Knowledge Network Research Paper Series at 14, online: <uakn.org/wpcontent/uploads/2014/08/2012-UAKN-Research-Paper-Series_Discrimination-and-Public-Perceptionsof-Aboriginal-People-in-Canadian-Cities_Dr.-Don-McCaskill.pdf>. Rudin, Criminal Justice System, supra note 24 at 36.

Bala, supra note 60 at 1011.

Marinos \& Innocente, supra note 65 at 481.

While a fulsome discussion of over-policing is beyond the scope of this article, it is important to note that this practice "is often associated with the targeting of individuals living in a specific neighbourhood, particularly in poor neighbourhoods. In this regard, it is not surprising to find that Aboriginal people are over-policed.” Rudin, Criminal Justice System, supra note 24 at 29. 


\section{B. Crown Prosecutors}

Once the police have initiated formal proceedings, the Crown becomes an extremely important gatekeeper for the remainder of the criminal justice process. Although more "visible" (and potentially more reviewable to a limited extent) than that of the police, the Crown's discretionary powers are also more expansive. ${ }^{74}$ While this article focuses on particular provisions of the YCJA that guide the Crown's ability to approve EJSs, it will become apparent that the Crown's discretionary influence impacts almost all aspects of a youth's proceedings from this point on; right through to sentencing. As such, the Crown's unique ability to expand or confine the options available to an eventual sentencing judge or even to ensure that the proceedings reach this stage - cannot be overstated. Given the crisis of Aboriginal overrepresentation detailed in this article, the Crown's impact on cases involving Aboriginal youth is all the more significant.

As mentioned above, the YCJA empowers the Crown to divert a youth from criminal proceedings by way of EJSs. ${ }^{75}$ Generally EJSs involve some type of specialized programming that is aimed at addressing the underlying criminogenic behaviour. A youth accused of shoplifting, for example, may be approved for programming that attempts to address the underlying lack of empathy that may have contributed to the decision to commit the offence. ${ }^{76}$ If this program is completed within the agreed upon timeframe, the Crown will stay the charges against the accused. Because the matter is diverted away from the courts if the program is successfully completed, the use of EJSs - like EJMs - has been held as a major contributor to the overall decline in youth custody rates. Again, the fact that Aboriginal youth custody rates have not declined as substantively as non-Aboriginal rates provokes questions regarding the potentially disproportionate use of EJSs.

Although less formal than proceedings requiring a formal plea, EJSs are still administered within the more structured confines of the CJS. As such, access to an EJS is more controlled and the implications of participation more substantive than for EJMs. As per the YCJA, an EJS may only be used if:

(a) it is part of a program of sanctions that may be authorized by the Attorney General or authorized by a person, or a member of a class of persons, designated by the lieutenant governor in council of the province;

(b) the person who is considering whether to use the extrajudicial sanction is satisfied that it would be appropriate, having regard to the needs of the young person and the interests of society;

By way of a non-exhaustive list, the Crown is empowered to: stay or withdraw the charges; approve formal diversion; contest a youth's bail application; offer a plea deal; and pursue an adult sentence that may or may not include a mandatory minimum depending on whether or not they choose to proceed summarily or by indictment. For a current foray into the topic of Crown discretion as it pertains to mandatory minimums for Aboriginal offenders, see $R v$ Anderson, 2014 SCC 41, [2014] 2 SCR 167 [Anderson]. In addition, the Crown may seek to establish aggravating circumstances in pursuit of a harsher youth sentence. Moreover, the Crown can also decide to seek a DNA order from a youth offender as per section 487.051 of the Code, supra note 6 - the constitutionality of which was upheld in the youth context in $R v R C$, 2005 SCC 61, [2005] 3 SCR 99.

YCJA, supra note 2, ss 10-12.

For example, the "Shoptheft Release Program” run by the Peel Police Services. Peel Police, "Shoplifting and Diversion,” online: <www.peelpolice.ca/en/services/shoptheftdiversionprogram.asp>. 
(c) the young person, having been informed of the extrajudicial sanction, fully and freely consents to be subject to it;

(d) the young person has, before consenting to be subject to the extrajudicial sanction, been advised of his or her right to be represented by counsel and been given a reasonable opportunity to consult with counsel;

(e) the young person accepts responsibility for the act or omission that forms the basis of the offence that he or she is alleged to have committed;

(f) there is, in the opinion of the Attorney General, sufficient evidence to proceed with the prosecution of the offence; and

(g) the prosecution of the offence is not in any way barred at law. ${ }^{77}$

The flipside of requiring youth to accept responsibility for the alleged incident as per section (e) is that an EJS will simply not be approved if they do not admit involvement in the commission of the alleged offence. ${ }^{78}$ Although this "admission" cannot be relied upon by the Crown as a substitute for a past "finding of guilt," previous participation in an EJS can be held as an aggravating factor in subsequent youth proceedings. ${ }^{79}$ Thus, Crown-initiated EJSs have both positive and negative implications for youth. While they can ultimately result in the case against the youth being dropped, they can also impact future proceedings in potentially negative ways. This article contends that for Aboriginal youth, this double bind is particularly problematic.

On one hand, Aboriginal youth may be less likely to even qualify for this type of diversion and are thus deprived of the benefits associated with EJSs. While dynamics of racism and systemic discrimination may infiltrate Crown offices in similar ways that police forces are affected, the lack of Aboriginal-appropriate programming also makes it less likely that an Aboriginal youth will receive an EJS. ${ }^{80}$ In short, if no programming is available, the Crown — no matter how attuned to the individual's needs, colonial history, and so on - simply cannot initiate an effective EJS. Although several successful programs do exist across Canada, ${ }^{81}$ they are not consistently funded. Because program funding is left up to the provinces, the potential benefits of EJS usage is subject to divergent political whims and sentiments. When one considers the relative voting power Aboriginal people exert on the political system, it is little wonder that funding for Aboriginal-centric EJS programming has not been made a top priority.

Supra note 2, s $10(2)$.

Ibid, s 10(3)(a).

Bala, supra note 60 at 1010 .

“Crown Referrals to Extrajudicial Sanctions (continued),” online: <www.justice.gc.ca/eng/cj-jp/yjjj/moyer_basic/decision/p4a.html> in Canada, Department of Justice, "Crown Decision-Making under the Youth Criminal Justice Act,” by Sharon Moyer \& Maryanna Basic (Ottawa: Department of Justice, March 2004). For recent data and analysis showcasing the lack of access to EJS by Aboriginal youth in Ontario, see Jonathan Rudin \& Liora Zimmerman, "The End is Not in Sight - The Over-Representation of Aboriginal Youth in Custody in Ontario 2004-2010” (2014) 60 Crim LQ 433 at 439-43.

ALST's “Community Council” program is often touted as a national model for Aboriginal-led diversion. "Community Council Program,” online: Aboriginal Legal Services of Toronto <www.aboriginal legal.ca/\#!community-council-program/c24vq>. 
On the other hand, even if appropriate programs exist and an Aboriginal youth is approved for an EJS, participation in that program is potentially less beneficial to that Indigenous young person. Recall that previous participation in an EJS can be held against a youth in subsequent proceedings. While this effectively mutes the potential benefit of being diverted on past occasions for any re-offending youth, the fact that Aboriginal youth experience a higher recidivism rate and come in greater contact with the CJS on a more regular basis, means that they are not benefitting as greatly from EJSs under the YCJA. Although the reasoning behind this deprivation is somewhat circular, this article suggests that it helps explain why Aboriginal youth overrepresentation in sentenced custody has not decreased in light of the EJS provisions in the YCJA.

\section{BAIL COURTS}

At the bail stage, the prior discretionary decisions of both the police and the Crown can be said to "come home to roost" under the YCJA in ways that adversely impact Aboriginal youth. Although detention in remand custody was presumptively unnecessary for youth as per section 29(2) of the YCJA, recent amendments to the Act have expanded the Crown's ability to rebut this presumption. ${ }^{82}$ In addition to outlining additional routes by which the Crown can convince a youth court judge or a justice (on a balance of probabilities) to remand a youth, ${ }^{83}$ the YCJA now contemplates past EJS participation as evidence that a youth is more likely to re-offend. Section 39(1)(c) previously stated that a youth justice court could commit a young person to custody if:

(c) the young person has committed an indictable offence for which an adult would be liable to imprisonment for a term of more than two years and has a history that indicates a pattern of findings of guilt. $^{84}$

However, the amended section (c) now states:

(c) the young person has committed an indictable offence for which an adult would be liable to imprisonment for a term of more than two years and has a history that indicates a pattern of either extrajudicial sanctions or of findings of guilt. ${ }^{85}$

Thus, the amended YCJA can be seen to effectively equate past EJS participation with formal findings of guilt. In doing so, the intrinsic benefit of an EJS is severely compromised for youth offenders who are statistically more likely to have repeated — and more serious interactions with the law. As discussed above, the circumstances of Aboriginal youths are more likely to lead to this unfavourable scenario.

More generally, the considerations at play during bail hearings tend to further disadvantage Aboriginal youth suffering from the societal ailments described at this article's outset. The near-necessity of having a surety is a significant obstacle for many Aboriginal youth whose families and communities have been shattered by colonialism's enduring

Supra note 2, s 29(2), as amended by Safe Streets and Communities Act, SC 2012, c 1, s 169. Ibid, s 29(2).

Ibid, s 39(1)(c) as it appeared on 22 October 2012 [emphasis added].

Ibid, s 39(1)(c) [emphasis added]. 
impact. Indeed, the simple lack of parental presence has also been found to negatively impact the success rate of bail applications - a trend that is also likely to disadvantage many Aboriginal youth. ${ }^{86}$ In addition, the Court's obligation to inquire into the availability of a "responsible person" ${ }^{\text {"87 }}$ before ordering detention is less likely to benefit Aboriginal youth given that many of the stereotypes applied to Aboriginal people are based on the notion that they are inherently less responsible due to addiction issues or perceived laziness. ${ }^{88}$ In short, these biases may prevent bail courts from substantively considering this unique YCJA provision before detaining an Aboriginal youth. As such, the youth bail process is substantively "stacked against” Aboriginal youth in subtle ways. ${ }^{89}$

Although the Gladue factors have been held to apply at the bail stage, ${ }^{90}$ the obstacles identified above function to inhibit the considerations emanating from section 718.2(e) of the Code and section 38(2)(d) of the YCJA. Some of these obstacles arise out of conflicting YCJA provisions. Others are activated at the Crown's discretion. ${ }^{91}$ As outlined above, the end result is an increased remand custody rate for Aboriginal youth.

\section{Probation OfFicers}

Although probation officers (POs) are generally perceived to occupy the post-sentence "space" of criminal proceedings, sentencing judges across the country have come to rely on POs to compile pre-sentence reports (PSRs) in order to assess the risks and needs pertaining to an individual offender. ${ }^{92}$ The reports themselves rely heavily on what are referred to as "risk/need" assessment models that help POs fashion appropriate recommendations for sentencing judges. ${ }^{93}$ More recently, the predictive veracity of these models when applied to Aboriginal people and other minorities has been questioned. Moreover, the legal appropriateness of relying on risk assessments at the expense of proportionality considerations has been raised in the context of the YCJA.

The assessment models used by POs are premised on actuarial "insurance models" that weigh static historic factors pertaining to the individual's background and dynamic criminogenic need variables that are considered amenable to treatment. ${ }^{94}$ Some of the risk/need factors that are assessed include: "criminal history (measured as number of

Michele Peterson-Badali \& Julia Broeking, “Parents’ Involvement in the Youth Justice System: Rhetoric and Reality” (2010) 52:1 Can J Corr 1 at 16-17.

YCJA, supra note 2, s 31(1).

For a poignant articulation of these stereotypes, see $R v$ Williams, [1998] 1 SCR 1128 at para 58.

To reiterate, this article does not suggest that all Aboriginal youth are adversely affected by these provisions and common law considerations. Rather, the circumstances in which many Aboriginal youth have been coercively placed tend to produce further disadvantage via the court process. For a refreshing example of a case in which this trend did not materialize see: $R v J D, 2005$ ONCJ 491, [2005] OJ No 5729 (QL).

Judge Brent Knazan, "Sentencing Aboriginal Offenders in a Large City - The Toronto Gladue (Aboriginal Persons) Court” (Paper delivered at the National Judicial Institute Aboriginal Law Seminar, Calgary, 23-25 January 2003), online: <lgdata.s3-website-us-east-1.amazonaws.com/docs/3978/ 843513/Knazan_smallpdf.com_.pdf $>$ at 11-14.

As stated by Varma, "the key decision-maker in youth bail court is the Crown Attorney. If the Crown Attorney did not contest release, every youth was released by the judge or justice of the peace." Kimberly N Varma, "Exploring 'youth' in court: An analysis of decision-making in youth court bail hearings” (2002) 44:2 Can J Crim 143 at 150.

Paula Maurutto \& Kenny Hannah-Moffat, "Understanding Risk in the Context of the Youth Criminal Justice Act” (2007) 49:4 Can J Corr 465 at 466, 468.

Ibid at 469.

Ibid at $469-70$. 
offences and not type of offence), education/employment, family circumstances, leisure/recreation, pro-criminal attitudes, substance abuse, anti-social patterns, and acquaintances." 95 Based on the assumption that higher needs translate into higher risks, an assessment of these variables produces an overall score that labels an offender as low, medium, or high risk to reoffend. ${ }^{96}$ Based on the realities facing Aboriginal communities in Canada, the weight given to static variables will often produce a higher "need" score for an Aboriginal youth which ultimately translates into labeling that youth as "higher risk." The Crown (or Defence depending on the score) then leverages this risk level during the pleabargaining process and formal sentencing proceedings. ${ }^{97}$

The use of these assessment models, therefore, can be seen to result in the imposition of more punitive sentences based on an assessment that is more indicative of a youth's socioeconomic status than the circumstances and seriousness of the actual offence. ${ }^{98}$ From this perspective, the predictive model has eclipsed the overarching principle of proportionality. In the case of Aboriginal youth in particular, there is a danger that the risk assessment contained in the PSR can derail the proper consideration of the Gladue factors contrary to the YCJA. As stated by the Saskatchewan Provincial Court in the case of $R$ v. T.D.P., there are serious "concerns for potential conflict between the purpose and principles of sentencing in the YCJA and the risk assessment tool." 99 While the courts are beginning to consider whether these concerns can be adequately addressed by controlling for potentially discriminatory factors, it is simply too early to gauge the success of these inquiries. ${ }^{100}$ As such, this article contends that POs - while well-intentioned — may function to inappropriately influence the sentencing process by relying on risk/need assessment models that perpetuate stereotypes regarding vulnerable groups of offenders.

\section{E. INHIBITING THE GLADUE CONSIDERATIONS: NON-JUDICIAL DISCRETION IMPACTS SENTENCING}

Having considered the impact of non-judicial actors in the CJS, it is clear that decisions made during the pre-sentence stages of youth justice proceedings can have significant "down stream” effects. Discretionary decisions made by the police and the Crown particularly guide the trajectory and outcome of a youth case. The use of EJMs and EJSs in response to a youth incident at the outset of a case can, for example, become relevant factors in a contested bail proceeding. The result of this proceeding — be it remand custody or the imposition of conditions - can, in turn, impact the likelihood of the youth pleading guilty. Moreover, the prospective plea deal might be swayed by an inherently flawed risk assessment detailed by a PO in a PSR. Ultimately, all of these pre-sentence junctures produce outcomes that can expand or restrict a sentencing judge's own discretionary purview.

Ibid at 477, citing $R v$ BHD, 2006 SKPC 32, 281 Sask R 191.

Maurutto \& Hannah-Moffat, ibid at 478.

$R v$ TDP, 2004 SKPC 57, 250 Sask R 3 at para 44.

For an encouraging example of the Courts being live to these concerns in the context of a psychological assessment of an Aboriginal offender for a Long-Term Offender Application, see Dr Lisa Ramshaw's evidence as reproduced by the Ontario Superior Court of Justice in $R v$ Lewis, 2012 ONSC 5085, [2012] OJ No $4522(\mathrm{QL})$ at para 93. 
From this perspective, this article argues that the pre-sentence use of discretion by nonjudicial actors has the ability to inhibit ultimate judicial discretion such that, in the youth context, considerations emanating from section 38(2)(d) of the YJCA and the Gladue-line of cases are precluded from constructively addressing Aboriginal youth overrepresentation in Canadian correctional services. As such, this article concludes by suggesting that the YCJA mandate the explicit consideration of Gladue-related factors by non-judicial actors in the exercise of their statutorily encouraged discretion.

\section{EXPANDING THE Focus: The GladUE PRINCIPLES Should Guide Pre-Sentence ProceEdings ANd THE EXERCISE OF NON-JUDICIAL DISCRETION}

Ultimately, this article suggests that the CJS has attempted to remedy Aboriginal youth overrepresentation by focusing too heavily on sentencing principles and judicial discretion. More attention must be paid to the earlier stages of the criminal justice process. In particular, the discretionary powers wielded by the police and Crown must be recognized as key variables in the over-incarceration equation. This article suggests that these variables must be brought into line with the Gladue principles in a renewed effort to turn back the rising tide of Aboriginal over-incarceration in Canada.

The Gladue jurisprudence is grounded in an appropriate understanding of the crisis of Aboriginal over-incarceration, such that it has widespread appeal beyond its original sentencing-centric focus. ${ }^{101}$ Importantly, the fact that the judiciary must explicitly engage the Gladue considerations as a reviewable matter of law has been central in ensuring a high level of use and accountability for non-use. ${ }^{102}$ In other words, the "high visibility" discretion exercised by the judiciary guarantees, to a certain extent, that Gladue is being applied appropriately. The problem identified by this article, is that this high visibility discretion is often obstructed earlier in the criminal justice process by the exercise of low visibility discretion that is: a) not required to consider an Aboriginal person's unique background, and; b) not subject to judicial oversight. In light of these deficiencies, this article proposes that in the youth context the police and the Crown should be required by statute to consider the Gladue factors in the course of their discretionary conduct.

Naturally, this proposition provokes many important questions regarding feasibility and the proper limits of discretion. While a proper investigation into these questions is well beyond the scope of this article, it is interesting to note that these issues already occupy a space in the Canadian jurisprudential landscape. As Bala has noted, the 1992 Supreme Court decision in $R$. v. T.(V.) $)^{103}$ still stands for the view that the judiciary only has the power to review police and Crown decision-making if there is a clear abuse of process. Here, the Court held that "[a] judge must keep out of the arena" 104 in order to preserve the sanctity of police investigations and the independent carriage of the Crown's case. This basic rationale has been invoked more recently in the context of Gladue's applicability to the Crown's 
discretionary power to seek a mandatory minimum sentence for an Aboriginal adult offender in the case of Anderson. ${ }^{105}$ Without delving too deeply into the debate over the appropriate standard of review for prosecutorial discretion, ${ }^{106}$ this article suggests that many of the concerns regarding judicial oversight may be less pointed under the YCJA. Indeed, given the $Y C J A$ 's principled recognition of a youth's reduced moral culpability and an Aboriginal youth's unique circumstances, ${ }^{107}$ this article closes by hypothesizing that the arguments advanced in cases like Anderson may encounter less opposition in the youth context. At the very least, this article suggests that it is high time for practitioners and legal scholars alike to reconsider the dicta in R. v. T.(V.) and the continued applicability of the Supreme Court of Canada's rationale under the YCJA.

\section{CONCLUSION}

This article has explored Aboriginal youth overrepresentation in correctional services under the YCJA in an attempt to discern why it has been less effective at reducing custody rates for Aboriginal youth compared to their non-Aboriginal peers. First, the historical legacy of colonialism and its intergenerational contribution to Aboriginal over-incarceration was canvassed. Next, the CJS's response to this crisis was discussed with an emphasis on section 718.2(e) and the Gladue line of cases. Then, the extent to which this response has been imported into the YCJA was noted. Having established this critical contextual anchor, this article then detailed the current state of Aboriginal overrepresentation in youth correctional services by looking more closely at the use of remand custody, custodial sentences, and probation. Next, non-judicial actors in the CJS were assessed. This article found that police, the Crown, bail courts, and probation officers function to effectively expand or confine the eventual range of sentencing options available — thus stymying any constructive impact the judicial consideration of a youth’s Aboriginality might otherwise have.

Ultimately, this article concludes that the CJS has attempted to remedy Aboriginal youth overrepresentation by focusing too heavily on sentencing principles and judicial discretion. It is argued that more attention must be paid to the earlier stages of the criminal justice process. Finally, this article proposes mandating the application of the Gladue principles to the discretionary power exercised by the police and the Crown. This proposition provokes a number of questions regarding practical and legal realities that the legal community would do well to address.

In closing, the YCJA reflects the complex feelings Canadians have toward youth crime and punishment. On one hand, we recognize the diminished moral culpability of young offenders and the value of rehabilitating our wayward youth. On the other hand, we remain shocked and appalled at serious and violent youth crimes and demand swift and harsh punishments in response. Codifying these somewhat conflicting sentiments, the YCJA provides for a number of alternatives to custody that are actualized, in part, by the exercise of non-judicial discretion. While this discretion has proven beneficial to youth offenders overall, it can also be seen to perpetuate the crisis of Aboriginal youth overrepresentation in correctional services. 
Just as Parliament saw fit to guide judges to explicitly consider an offender's Aboriginality, Parliament should so direct non-judicial actors in the youth CJS. While such a mandatory consideration of the Gladue principles by the police and Crown is likely to provoke much criticism, the deepening crisis of Aboriginal youth over-incarceration necessitates bold action and attention beyond the CJS's current focus on sentencing. 